\title{
CEPHALANTHERA ERICIFLORA SZLACH. \& MYTNIK, SP. NOV. (ORCHIDACEAE, NEOTTIOIDEAE), A NEW SPECIES FROM LAOS
}

\author{
Dariusz L. SzlachetKo*, JoAnna MytniK-EjSmont, Hanna B. MargońsKa \\ Departemnt of Plant Taxonomy and Nature Conservation \\ Al. Legionów 9, 80-405 Gdańsk, Poland \\ *e-mail: biodarek@univ.gda.pl
}

(Received: February 21, 2007. Accepted: July 26, 2007)

\begin{abstract}
A new orchid species, Cephalanthera ericiflora Szlach. \& Mytnik, sp. nov. is described and illustrated. Its taxonomic position is briefly discussed.
\end{abstract}

KEY WORDS: Orchidaceae, Neottioideae, Cephalantherinae, Cephalanthera, Laos.

\section{INTRODUCTION}

The subfamily Neottioideae Lindl. was described by Lindley in 1826. It has received different treatments by various authors. Garay (1972) included three tribes within Neottioideae: Neottieae Lindl., Epipogieae Parlatore and Cranichideae Endl. Dressler (1981) did not distinguished the subfamily and classified the "neottioid" taxa into widely defined Orchidoideae. Rasmussen (1985) recognized only two tribes in his concept of Neottioideae: Epipactieae Endl. and Neottieae. A basically different classification of Neottioideae was proposed by Burns-Balogh and Funk (1986). They distinguished four tribes within the subfamily: Neottieae, Thelymitreae Endl., Geoblasteae Barb.Rodr. and Pterostylideae (Pfitz.) van Royen. Dressler (1993) classified Neottieae into Epidendroideae Lindl. stating that this is an evolutionary old and isolated group being not very close to Epidendroideae, but even less to Orchidoideae or Spiranthoideae Dressl. Cameron et al. (1999) and Pridgeon et al. (2006) also included Neottieae under Epidendroideae s.1.

Szlachetko (1995) recognized neottioids as a separate subfamily close to Epidendroideae s.s. The author distinguished two tribes, Diceratosteleae Dressl. and Neottieae. According to the author the former tribe embraces two monotypic subtribes: Cephalantherinae Pfitz. and Diceratostelinae (Dressl.) Szlach. In Neottieae Szlachetko recognized five genera classified in two subtribes: Limodorinae Benth. and Neottiinae Rchb.f. (=Listerinae Lindl. ex Meisn.). Neottioideae sensu Szlachetko 1995 embrace the most primitive members of the monandrous orchids and include genera with a very simple type of gynostemium, rhizomatous type of growth and terrestrial habit.
The most primitive genera within Neottioideae sensu Szlachetko (1995) are Diceratostele Summerh. and Cephalanthera L.C. Rich. The species of Cephalanthera are characterized by an erect anther with a distinct filament, four narrowly cylindrical, very soft, and friable pollinia, lack of distinct rostellum not producing any viscidium, with two digitate, finger-like stamonodia and with 3-lobed stigma. On the other hand flowers of Cephalanthera produce pseudopollen and thus deceive the pollinators. Cephalanthera occupies much of the temperate and subtropical zones of the Northern Hemisphere (about 20 species). The most of them is distributed in the Mediterranean Sea basin. One species occurs in North America ( $C$. austinae Benth. \& Hook.f.) and a few in south-east Asia.

Neottioideae contain a very high proportion of holomycotrophic species (33\% according to Dressler 1993) that are thought to represent multiple losses of photosynthesis. There is a clearly seen wide range of different levels of chlorophyll, i.e. in Cephalanthera. The species from Central Europe produce normal leaves as it is observed in most other groups of vascular plants. However leaves of the species from eastern Mediterranean are often transformed into small scales. The obligate holomycotroph within Cephalanthera is exlusively western American C. austinae Benth. \& Hook.f. (Luer 1975). Some saprophytic and semisaprophytic species occur in Asia (i.e. Cephalanthera exigua Seidenf., the only one leafless species from Laos). The next achlorophyllous species, not described yet, was collected by A.F.G. Kerr from Laos, too.

\section{DESCRIPTION}

Cephalanthera ericiflora Szlach. \& Mytnik, sp. nov. (Fig. 1). 


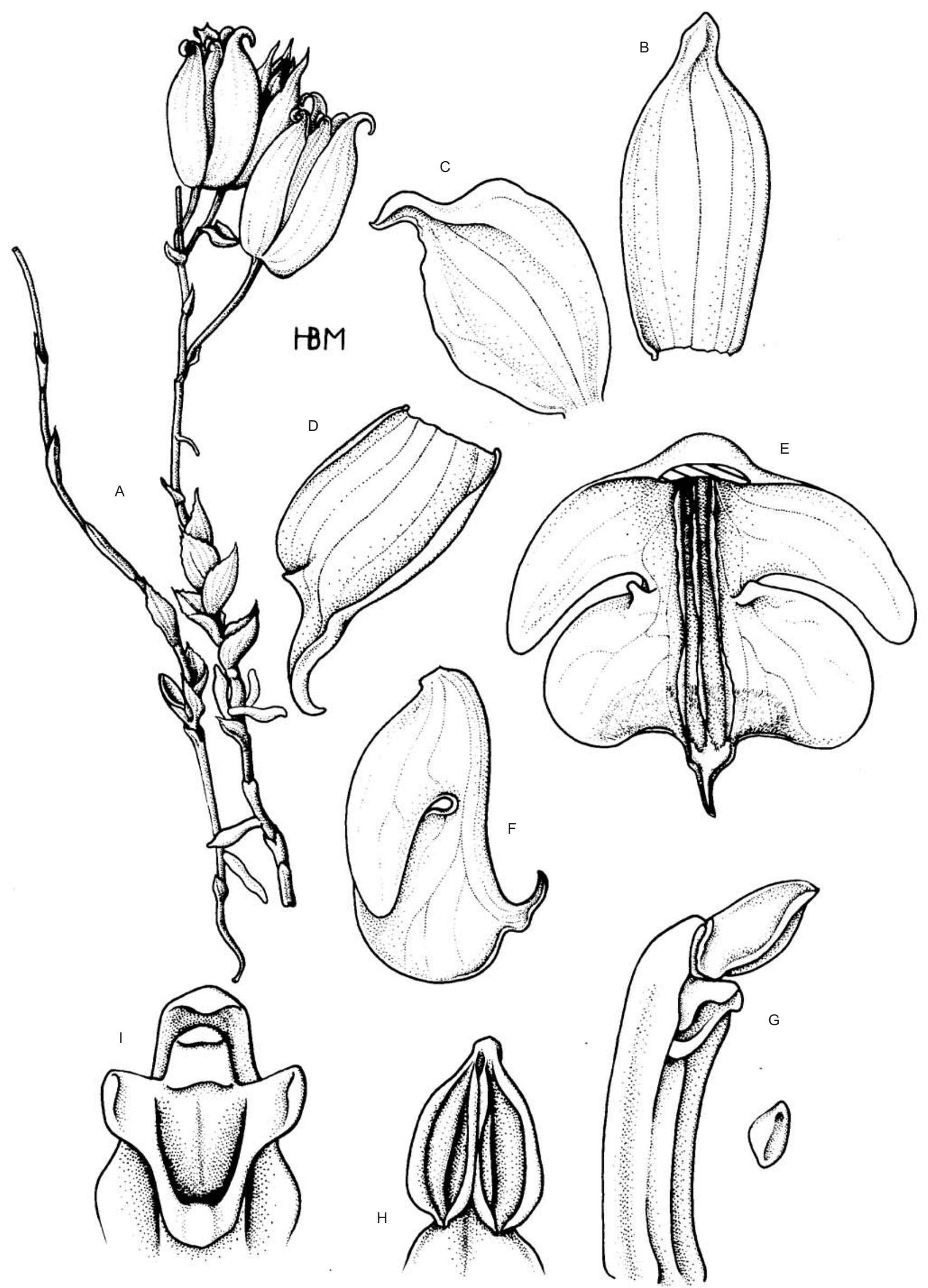

Fig. 1. Cephalanthera ericiflora Szlach. \& Mytnik: A - Plant; B - Dorsal sepal; C - Petal; D - Lateral sepal; E - Lip, flattened; F - Lip, side view; G - Gynostemium side view and pollen grain; H - Anther; I - Receptive surface, spread (drawn from the holotype by Hanna B. Margonska, UGDA, Kerr s.n., BM). 
Species C. exiguae pertinens, floribus campanulatis, apicibus petalorum caudatis, labellis trilobatis tres lamellis secus nervos habentem, apice lobi centralis crasso jam dignoscendum.

Type

Laos. Pu Tat, Niengchan, montane evergreen forest. Alt. 1200 m. 22 April 1932. Kerr s.n. (BM! - holo).

\section{Etymology}

An allusion to the flower form similar to various species of Erica (Ericaceae).

Stem 5-7 cm long, erect, delicate. Rhizome arising, with scattered roots, ca. $1 \mathrm{~cm}$ long, and distantly covered by scale-like sheaths. Leaves $4-5$, up to $1 \mathrm{~cm}$ long and to 0.5 $\mathrm{cm}$ wide, imbricating, ovate, acute, gathered in the lower third of the stem. Inflorescence ca. $2 \mathrm{~cm}$ long, few-flowered. Flowers relatively large, Erica-like, constricted below the apex, with reflexed apical parts of the perianth segments. Floral bracts 2-3 mm long, ovate, acute, scale-like. Pedicel and ovary up to $14 \mathrm{~mm}$ long, slender. Dorsal sepal $11 \mathrm{~mm}$ long, 4-5 mm wide, oblong-obovate, apiculate, 5nerved. Petals 9-10 mm long, $5 \mathrm{~mm}$ wide, elliptic to elliptic-obovate, apiculate, 5-nerved, lateral nerves branching. Lateral sepals $11.5 \mathrm{~mm}$ long, $6 \mathrm{~mm}$ wide, oblong-elliptic, long apiculate, 5-nerved. Lip about $10 \mathrm{~mm}$ long in total, 14 $\mathrm{mm}$ wide when spread, constricted near the middle, with three lamellae running from the base almost to the apex; hypochile sac-like, lateral lobes $7 \mathrm{~mm}$ long, $3.5 \mathrm{~mm}$ wide at the base, falcate, obtuse; epichile $5 \mathrm{~mm}$ long, $10 \mathrm{~mm}$ wide, transversely elliptic, 3-lobed at the apex, apical part long apiculate, thickened, papillate. Gynostemium $10 \mathrm{~mm}$ long, slender, slightly arcuate.

\section{Notes}

The species appears to be closely related to $C$. exigua from Laos. Both are very small, inconspicuous plants with the lower third of the stem covered by enveloping sheaths. In both species inflorescence is single- to few-flowered with relatively large flowers, but the flower segments in $C$. ericiflora are acuminate with reflexed apical parts. The lip is deeply constricted near the middle with falcate, obtuse side lobes of hypochile. The epichile is transversely elliptic, with apiculate, thickened apex. In $C$. exigua perianth parts - except the lip - are acute, not apiculate. Seidenfaden (1992) describing his species stated that he was uncertain about the ornamentation of the type specimen. In $C$. ericiflora there are three lamellae along the lip - from its base almost to the apex. The apical part of epichile is densely papillate.

C. ericiflora can be compared with two other saprophytic species described from China $-C$. calcarata S.C. Chen \& K.Y. Lang (Chen and Lang 1986) and C. gracilis S.C. Chen \& G. Zhu (Chen and Zhu 2002). In both latter species, flowers produce prominent, conical spurs at the base, the epichile is nearly as long as wide, acute or obtuse and ornamented by five lamellae. In none of them the flower segments are apiculate.

\section{ACKNOWLEDGMENTS}

We are grateful to Dr. Jerzy Bohdanowicz (Laboratory of Cytology and Plant Embryology, Gdansk University, Poland) for SEM photographs of the pollen grains. The senior author wishes to express his gratitude to Stephan Gale (Royal Botanic Gardens, Kew) for inspiring discussion and to Dr. Roy Vickery, the Curator of BM, for his hospitality during personal visits.

\section{LITERATURE CITED}

BURNS-BALOGH P., FUNK. V.A. 1986. A phylogenetic analysis of the Orchidaceae. Smiths. Contr. Bot. 61: 1-79.

CHEN S.C., LANG K.Y. 1986. Cephalanthera calcarata, a new saprophytic orchid from China. Acta Bot. Yunnanica 8 (3): 271-274.

CHEN S.C., ZHU G.H. 2002. Cephalanthera gracilis (Orchidaceae), a new species from China. Acta Bot. Yunnanica 24 (5): 600-602.

DRESSLER R.L. 1981. The orchids, natural history and classification. Harvard Univ. Press, Cambridge, 332 pp.

DRESSLER R.L. 1993. Phylogeny and classification of the orchid family. Dioscorides Press, Portland, $312 \mathrm{pp}$.

GARAY L.A. 1972. On the origin of the Orchidaceae. II. J. Arnold. Arbor. 53: 202-215.

LINDLEY J. 1826. Collectanea Botanica. Appendix. s.n.

LUER C.A. 1975. The native orchids of the United States and Canada excluding Florida - New York Botanical Garden, New York, NY. 361 pp.

RASMUSSEN F.N. 1985. Orchids. In: R. Dahlgren, H.T. Clifford, P.F. Yeo (eds), The families of monocotyledons - structure, evolution, taxonomy. Springer Verlag, Berlin, pp. 249-274.

SZLACHETKO D.L. 1995. Systema Orchidalium. Fragm. Flor. Geobot., Suppl. 3: 1-152. 